\title{
Vihapuhe tiedontarpeiden virittäjänä
}

\author{
Ari Haasio \\ Seinäjoen ammattikorkeakoulu \\ ari.haasio@seamk.fi \\ https://orcid.org/0000-0003-3723-4890
}

Anu Ojaranta

Åbo Akademi

anu.ojaranta@abo.fi

https://orcid.org/0000-0002-8471-8778

Markku Mattila

Siirtolaisuusinstituutti

markku.mattila@utu.fi

https://orcid.org/0000-0003-3733-6723

Asiasanat: tiedontarve; tiedonhankinta; vihapuhe; tunteet

Turussa 18.8.2017 tapahtuneiden puukotusten yhteydessä ilmenneitä tiedontarpeita käsittelevässä tutkimuksessa (Haasio ym., 2018a) havaittiin affektiivisten tekijöiden olevan keskeisessä roolissa terrorihyökkäykseen liittyvien tiedontarpeiden virittäjänä. Tutkimusmateriaali koostui kolmestatoista ensimmäisestä, Turussa tapahtuneita puukotuksia koskeneista Yleisradion Facebook-päivityksistä ja niihin tulleista kommenteista. Aineisto sisältää kaiken kaikkiaan 1930 kommenttia.

Nyt tekeillä olevan tutkimuksen fokus on vihapuheeksi luokiteltavan puheen ja vihaisen puheen (vrt. Haasio ym., 2018b) ilmenemisessä tiedontarpeita artikuloitaessa. Hypoteesimme on, että useissa tapauksissa tiedontarpeiden laukaisijana toimivat affektiiviset motiivit (vrt. Kuhlthau, 1993; Choo, 2002). Jo tehdyssä tutkimuksessa on havaittu affektiivisten tekijöiden iso osuus tiedontarpeita selittävänä tekijänä. Ennen kaikkea pelon, vihan ja surun ilmaukset 
artikuloituivat tiedontarpeiden eksplisiittisissä ilmauksissa (Haasio ym., 2018a). Nyt syvennämme tietämystä tiedontarpeiden syntyy vaikuttavista affektiivisista tekijöistä.

Tutkimusta on jatkettu analysoimalla ilmenneiden tiedontarpeiden ilmaisuja nojautuen sekä sisällönanalyysiin (vrt. Tuomi \& Sarajärvi, 2002) että Charles S. Peircen kehittämään semioottiseen analyysiin (esim. Peirce, 1991). Bergmanin (1998) mukaan Peircen semanttinen analyysi korostaa nimenomaan merkityksen kontekstuaalista syntyprosessia merkityksiä tulkittaessa. Tunteiden luokittelussa nojaudumme Charles Darwinin tekemään tunteiden jaotteluun. Hänen mukaansa perustunteita ovat pelko, viha, suru, inho, yllätys, onnellisuus, kiinnostus ja häpeä (Darwin, ei pvm.).

Jatkotutkimuksen keskeiset tutkimuskysymykset ovat:

1. Mitkä tunteet vaikuttavat poikkeuksellisessa terrori-iskussa syntyviin tiedontarpeisiin ja kuinka ne artikuloidaan?

2. Kuinka a) vihainen puhe ja b) vihapuhe artikuloituu tiedontarpeissa?

3. Millaisten kielellisten ilmaisujen avulla vihapuhe ilmenee ryhmään lähetetyissä viesteissä?

Selvitämme tiedontarpeiden tilannekohtaisuuteen (vrt. Savolainen, 2012) liittyvien affektiivisten faktoreiden merkitystä tiedontarpeen muotoutumisessa ja sitä, kuinka nämä faktorit näkyvät konkreettisina kielellisinä ilmaisuina. Oletuksena on, että sanavalintojen ja kirjoitustyylin perusteella voidaan havaita kirjoittajan voimakas tunnepitoinen motiivi, joka herättää tiedontarpeen.

Vihaisella puheella tarkoitamme sosiaalisten normien vastaista puhetta, jolle on tyypillistä voimasanojen käyttö, henkilökohtaiset solvaukset tai sellaisiksi tarkoitetut ilmaukset, joita saatetaan tehostaa suorilla tai verhotuilla uhkauksilla. Pöyhtärin ja kumppaneiden (2013) mukaan kyse on hyvien tapojen vastaisesta ja leimaavasta kielenkäytöstä. Vihapuheen määrittelyssä nojaudumme Tampereen yliopiston COMET-tutkimuskeskuksen näkemykseen, jonka mukaan "vihapuhe on Suomen lainsäädännön lähtökohdista vähemmistöryhmiä leimaavaa ja halventavaa puhetta, jossa voidaan myös yllyttää väkivaltaan ko. ryhmiä kohtaan" (Henttonen, Kivinen, Rasila, Sammalmaa, \& Vihavainen, 2015, s. 22).

Alustavassa analyysissä on havaittu ennen muuta pelon, vihan, surun, inhon ja yllätyksen tunteiden vaikuttavan affektiivisten tiedontarpeiden syntyyn terrori-iskuun liittyvissä tiedontarpeissa. Osassa näistä tunneilmaisuista voidaan selkeästi havaita niin vihaisen puheen kuin vihapuheenkin elementtejä, mikä tarjoaa kiintoisan näkökulman affektiivisten, tiedontarpeisiin vaikuttavien tekijöiden analyysiin. Vihaisen puheen ilmaisuina voidaan alustavan analyysin perusteella mainita esimerkiksi alatyyliset ja kielellisen hyvän tavan vas- 
taisen ilmaisut (mm. kiroilu), uhkaukset, vihaiseksi puheeksi katsottava kielikuvien käyttö ("saunan takana on tilaa"), etnisyyteen ja uskontoon kohdistuvat halventavat kielikuvat (“ählämi” yms.) sekä rasistiset ilmaukset ("mutakuono", "neekeri" yms.).

Vihaisen puheen ja vihapuheen lisäksi affektit ilmenevät myös normatiivisesti hyväksyttävänä kielenkäyttönä, josta esimerkkinä ovat erilaiset kauhistelut ("ei voi olla totta") tai avoimet suorat tunneilmaisut ("surullista").

\section{Lähteet}

Bergman, M. (1998). Viestintä, tulkinta ja toiminta: Peircen semiotiikka viestinnän tutkimuksessa. Tiedotustutkimus, 21(4). https://doi.org/10.23983/mv.61400

Choo, C. W. (2002). Information management for intelligent organization: the art of scanning the environment. New Jersey: Information Today.

Darwin, C. (ei pvm.). Tunteiden ilmaisu ihmisissä ja eläimissä. (A. Leikola, käänt.). Terra Cognita.

Haasio, A., Mattila, M., Ojaranta, A., \& Kannasto, E. (2018a). Terrori-isku tiedontarpeiden virittäjänä: Turun puukotusten aiheuttamat tiedontarpeet. Informaatiotutkimus, $37(2)$. https: //doi.org/10.23978/inf.71157

Haasio, A., Ojaranta, A., \& Mattila, M. (2018b). Valheen jäljillä. Helsinki: Avain.

Henttonen, S., Kivinen, T., Rasila, T., Sammalmaa, J., \& Vihavainen, J. (2015). Kommentaari. Teoksessa R. Neuvonen (toim.), Vihapuhe Suomessa (ss. 13-135). Helsinki: Edita.

Kuhlthau, C. C. (1993). Seeking meaning : a process approach to library and information services. New Jersey: Ablex.

Peirce, C. S. (1991). Peirce on signs : writings on semiotic. (J. Hoopes, toim.). Chapel Hill: University of North Carolina Press.

Pöyhtäri, R., Haara, P., \& Raittila, P. (2013). Vihapuhe sananvapautta kaventamassa. Tampere: Tampere University Press. http://urn.fi/URN: ISBN: 978-951-44-9249-5

Savolainen, R. (2012). Conceptualizing information need in context. Information Research, 17(4). http://Www.informationr.net/ir/17-4/paper534.html

Tuomi, J., \& Sarajärvi, A. (2002). Laadullinen tutkimus ja sisällönanalyysi. Helsinki: Tammi. 